WACLAW ORCZYK

MARTA DMOCHOWSKA-BOGUTA

YULIYA KLOC

Instytut Hodowli i Aklimatyzacji Roślin — Państwowy Instytut Badawczy, Radzików, Zakład Inżynierii Genetycznej

Kierownik Tematu: prof. dr hab. Wacław Orczyk Instytut Hodowli i Aklimatyzacji Roślin — Państwowy Instytut Badawczy, Radzików, Zakład Inżynierii Genetycznej, 05-870 Błonie, tel. 22 7334621, e-mailw.orczyk@ihar.edu.pl

Prace zostały wykonane $w$ ramach badan podstawowych na rzecz postęp biologicznego $w$ produkcji roślinnej na podstawie decyzji Ministra Rolnictwa $i$ Rozwoju Wsi nr HOR.hn.802.19.2018, Zadanie 8.

\title{
Tolerancja na stresy abiotyczne - genotypowanie pszenicy w oparciu o strategię genów kandydujących
}

Tolerance for abiotic stresses - genotyping of wheat based on candidate gene strategy

Słowa kluczowe: genom pszenicy, mikrosporogeneza, sekwencje mikrosatelitarne, susza, wypełnienie kłosa, żywotność pyłku

CELE TEMATÓW W ROKU 2018

— Sekwencjonowanie fragmentów gDNA pszenicy $\mathrm{z}$ określonymi regionami SSR w genotypach pszenic różniących się tolerancją na stres suszy $w$ czasie mikrosporogenezy.

— Eksperymentalna weryfikacja poznanych sekwencji w genotypach pszenic różniących się tolerancją na stres suszy w czasie mikrosporogenezy.

\section{WYNIKI}

W trzech skafoldach pszenicy zawierających wybrany gen kandydujący TaInv1 sekwencjonowano 9 regionów SSR. Były to Reg29-404 zawiera dwa motywy (CT)2-AC-(CT)6 i jest zlokalizowany na skafoldzie 4041295BL, Reg32-404 zlokalizowany na skafoldzie 404129 5BL zawiera dwa sprzężone motywy (CAGC)3-(AAGA)5, Reg35-404 zlokalizowany na skafoldzie 404129 5BL zawiera sekwencję mikrosatelitarną z motywem AG powtórzoną 18 razy, Reg41-404 zlokalizowany na skafoldzie 404129 5BL zawiera dwa sprzężone motywy 
(GGC)5-(GCG)5 oraz Reg3-435 zlokalizowany na skafoldzie 435640 5DL zawiera dwa sprzężone motywy (GAT)10-(GAA)9.

\section{PODSUMOWANIE I WNIOSKI}

1. Na wszystkich analizowanych skafoldach genomu pszenicy zidentyfikowano sekwencje mikrosatelitarne (SSR).

2. Najwięcej SSR było na najdłuższym skafoldzie 4041295BL, na tym skafoldzie zagęszczenie SSR było największe, 1 SSR na 10 tysięcy pz (tpz).

3. Wśród zidentyfikowanych SSR motywy 2-nukleotydowe były w 6 SSR, motyw 3-nukleotydowy był w 3 SSR. Przeważały motywy niedoskonałe tj. przedzielone krótką wstawką. W 2 przypadkach regionom SSR towarzyszył region o niepoznanej sekwencji nukleotydowej.

4. Projektowanie starterów $\mathrm{w}$ praktycznie wszystkich regionach napotkało duże trudności ze względu na i) nierównomierny rozkład par AT i GC w obszarach flankujących SSR, ii) znacznie zwiększony udział AT lub GC w całym regionie i iii) niedoskonałe powtórzenia kilkunukleotydowych motywów w regionach gdzie powinny być startery do amplifikacji.

5. Wyniki sekwencjonowania potwierdziły obecność regionów SSR wytypowanych we wcześniejszych analizach in silico w badanych genotypach pszenic.

6. Wyniki sekwencjonowania regionów SSR wykazały polimorfizm długości tych regionów w wybranych genotypach pszenic.

7. Rozdziały elektroforetyczne amplikonów zawierających regiony SSR potwierdziły polimorfizm długości tych regionów w 12 testowanych genotypach pszenic.

8. Dla przynajmniej czterech regionów zawierających sekwencje mikrosatelitarne polimorfizm zidentyfikowany po sekwencjonowaniu był również obserwowany po rozdziale amplikonów w żelu poliakrylamidowym. W kolejnym etapie analizowana będzie zbieżność tych polimorfizmów $\mathrm{z}$ obserwowanymi wcześniej danymi żywotności pyłku i stopnia wypełnienia kłosów. 